\title{
Amygdala Regulation of Fear and Emotionality in Fragile X Syndrome
}

\author{
Jose Luis Olmos-Serrano' Joshua G. Corbin \\ Center for Neuroscience Research, Children's Research Institute, Children's National Medical Center, \\ Washington, D.C., USA
}

\section{Key Words}

Amygdala - Animal model - Behavior - Fear conditioning • Fragile $\mathrm{X}$ syndrome $\cdot \mathrm{GABA} \cdot$ Mental illness $\cdot$ Fear .

Emotions $\cdot$ Inhibitory circuits

\begin{abstract}
Fear is a universal response to a threat to one's body or social status. Disruption in the detection and response of the brain's fear system is commonly observed in a variety of neurodevelopmental disorders, including fragile $X$ syndrome (FXS), a brain disorder characterized by variable cognitive impairment and behavioral disturbances such as social avoidance and anxiety. The amygdala is highly involved in mediating fear processing, and increasing evidence supports the idea that inhibitory circuits play a key role in regulating the flow of information associated with fear conditioning in the amygdala. Here, we review the known and potential importance of amygdala fear circuits in FXS, and how developmental studies are critical to understand the formation and function of neuronal circuits that modulate amygdala-based behaviors.

Copyright ๑ 2011 S. Karger AG, Basel
\end{abstract}

1 Present address: Department of Anatomy and Neurobiology, School of Medicine, Boston University, Boston, Mass., USA.

\section{Introduction}

The first steps toward discovery of the human genetic disease fragile X syndrome (FXS) began in 1943 in a pedigree reported by James Purdon Martin, an English physician, and Julia Bell, an English geneticist, who together observed intellectual disability in 11 males consistent with an X-linked problem [1]. This study led the geneticist Herbert Lubs [2] in 1969 to microscopically examine the $\mathrm{X}$ chromosome from family members with intellectual disability. Lubs observed and described a constriction near the end of the long arm of the $\mathrm{X}$ chromosome (Xq27.3) in cultured cells from 4 intellectually disabled males and 2 mentally normal females. This constriction made the $\mathrm{X}$ chromosome appear broken, and therefore became known as the 'fragile' X chromosome. In 1977, Grant Sutherland [3], who was studying the occurrence of fragile sites, discovered that the ability to detect fragile sites was dependent on the chemicals used to study patients' chromosomes. Sutherland discovered that using the medium 199 gained instant access to the fragile sites, which helped develop the first test for FXS. Further cytological studies of males from the original Martin and Bell pedigree showed that they possessed the fragile $\mathrm{X}$ site, and intellectual disability associated with a fragile $\mathrm{X}$ chromosome was then termed Martin-Bell syndrome, today known as FXS.

\section{KARGER}

() 2011 S. Karger AG, Basel

Fax +4161306 1234

E-Mail karger@karger.ch

www.karger.com
Accessible online at: www.karger.com/dne
Joshua G. Corbin

Center for Neuroscience Research, Children's National Medical Center

111 Michigan Ave. N.W.

Washington, DC 20010 (USA)

E-Mail JCorbin@cnmcresearch.org 
FXS is an X-linked inheritable disease, and it is one of a group of genetic conditions that also includes fragile $\mathrm{X}$ associated tremor/ataxia syndrome and fragile $\mathrm{X}$-associated primary ovarian insufficiency, collectively called fragile X. FXS is a neurodevelopmental disorder accounting for the most common cause of inherited mental impairment ranging from intellectual disability to learning problems. Males are typically more severely affected than females. While most boys have intellectual disabilities, only one third to one half of girls have significant intellectual impairment; the rest have either a normal IQ or lesser learning disabilities (reviewed in Hagerman [4]). Females are usually less affected as they have two X chromosomes; therefore, random $\mathrm{X}$ inactivation in each cell determines the intellectual level and physical involvement caused by the fragile X mutation. Also, both males and females usually present behavioral and emotional problems, even with a normal IQ, such as attention deficit hyperactivity disorder, anxiety, unstable mood, impulsivity, aggressiveness, poor eye contact, shyness, self-talk, hyperarousal to sensory stimuli, hand flapping, and hand biting (reviewed in Hagerman [4]). Most FXS patients also present some physical features including prominent ears, soft skin, flat feet, and loose connective tissue that leads to hyperextensible joints, especially fingers. In addition, macroorchidism, long face and high arched palate are present in adulthood. Seizures (epilepsy) also occur in about $25 \%$ of people with FXS. Interestingly, while some FXS patients tend to be very social and interested in other people, approximately $30 \%$ of those with FXS are diagnosed with autism, and pervasive developmental disorders not otherwise specified occur in an additional 30\% (reviewed in Hagerman [4]). However, it has recently been reported that there are significant differences in the profile of social and communicative symptomatology in FXS compared with individuals diagnosed with idiopathic autism [5]. Despite these differences, this high rate of autism diagnosis makes the fragile $\mathrm{X}$ mutation the leading known single-gene mutation causing autism (reviewed in Hagerman [4]).

In 1991, the fragile X mental retardation 1 (FMR1) gene was discovered [6] (fig. 1a). FXS is mainly caused by the trinucleotide CGG repeat expansion mutation $(>200$ repeats, full mutation) in the promoter region of the FMR1 gene leading to hypermethylation and resulting in transcriptional silencing of the gene (fig. 1b). The FMR1 gene encodes the fragile $\mathrm{X}$ mental retardation protein (FMRP), an mRNA-binding protein that is highly expressed in testis, and in fetal and adult brain, with the majority of signals localized to neurons [7-9]. This gene belongs to a small gene family that also includes the fragile-X-related 1 and 2 genes (FXR1 and FXR2). FXR1 and FXR2 are autosomal genes mapping to chromosomes 3q2 and 17p13.1, respectively [10], and to our knowledge neither FXR1 nor FXR2 have been associated with any known pathology or defect. The discovery that amplification of trinucleotide repeats which, in most cases, is the molecular basis of the FXS revealed a new mechanism of transgenerational inheritance. This finding was soon followed by discoveries of other diseases in which triplet amplifications at the DNA level are responsible for the disease phenotype such as myotonic dystrophy, Huntington's disease and spinocerebellar ataxia type 1 [11].

The identification of a disease human gene and its mutation(s) provided new possibilities for early diagnosis of patients, carrier detection and prenatal diagnosis. For example, this repeat length in individuals can be determined using Southern blotting and polymerase chain reaction, and thus can be used in DNA diagnostics. However, in order to gain a deeper understanding of the genetic consequences of such genomic changes and the pathogenesis of the disease, the mutation(s) needed to be included in experimental models. Toward this goal, 3 years after the discovery of the FMR1 gene, the mouse model of FXS was generated by a consortium of the Oostra and Willems laboratories [12]. As the mouse CGG repeat expansion does not seem to occur as seen in humans, the mouse model was created by a straightforward gene deletion, resulting in a complete Fmrl loss of function (fig. 1c). Despite the differences in the underlying genetic lesion, the Fmrl knockout (KO) mouse replicates many of the human features. For example, both human FXS patients and Fmrl $\mathrm{KO}$ mice present abnormal dendritic spine morphology, macroorchidism, spatial learning deficits, audiogenic seizures, and a number of abnormal behaviors such as hyperactivity, impaired social interaction, and abnormal anxiety-related responses [12, 13]. Thus, the Fmrl KO mouse has provided an accurate molecular model of the human condition and is one of the best current models of a human neurodevelopmental disorder.

Extensive studies in the Fmrl KO mouse have proven extremely valuable to gain insight regarding the specific role that FMRP plays in neuronal development and function. As an mRNA-binding protein, FMRP selectively binds approximately $4 \%$ of mRNAs in the mammalian brain (reviewed in Bassell and Warren [14]). FMRP is associated with actively translating polyribosomes in both cultured neuronal and nonneuronal cells, in brain synaptoneurosomes $[15,16]$ as well as regulating protein syn- 


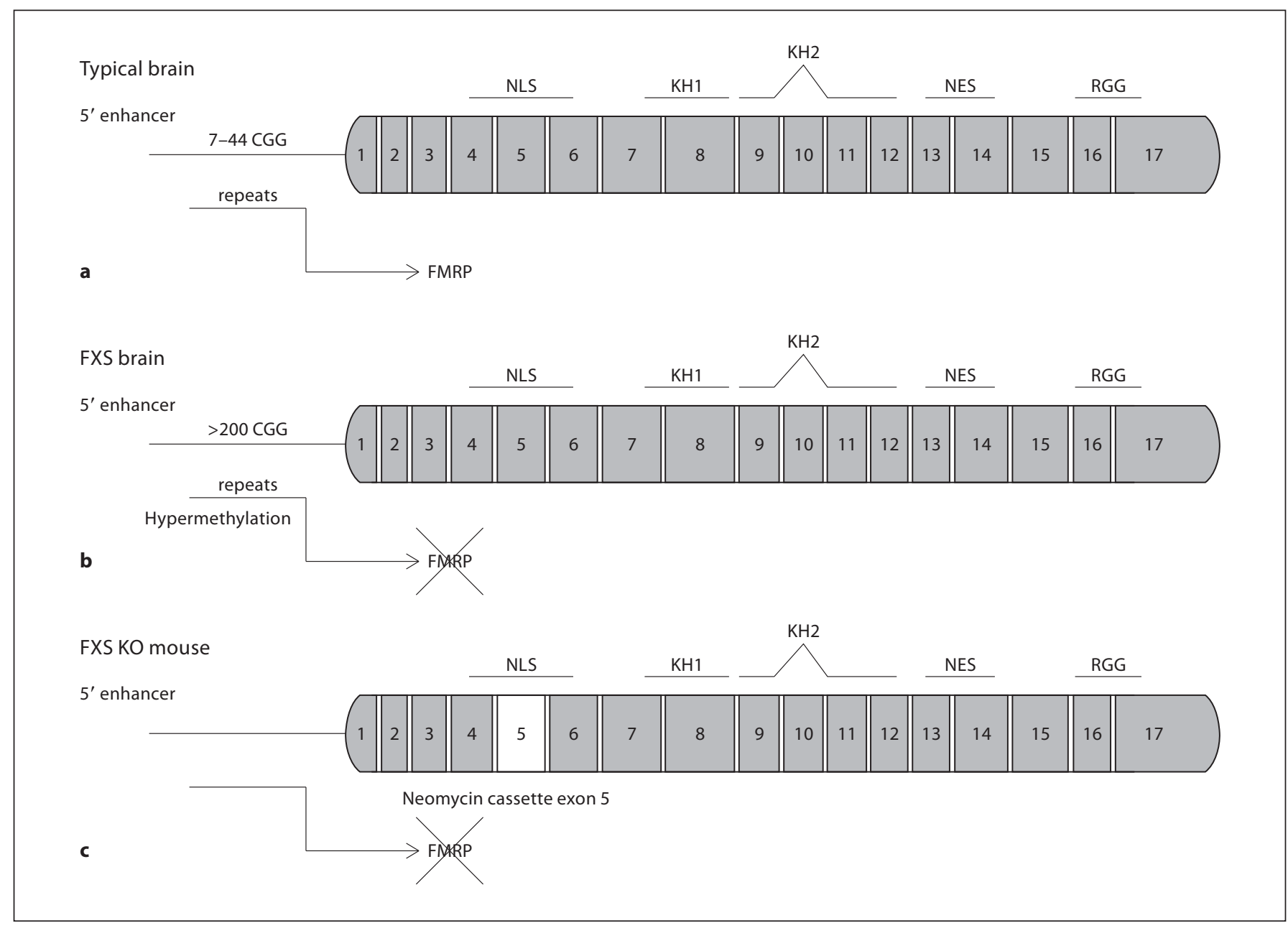

Fig. 1. Schematic representation of the FMR1 gene in a typical brain (a), in an FXS brain (b), and in the Fmr1 KO mouse (c). NLS = Nuclear localization signal; KH = hnRNP K-protein homology domains; NES = nuclear export signal; RGG = arginineglycine-glycine. The FMR1 gene is composed of 17 exons. The normal number of CGG repeats in a typical brain produces FMRP (a). Full mutation of the FMR1 gene is reached when the $5^{\prime}$ en- hancer is hypermethylated due to the presence of more than 200 CGG repeats (b). The Fmrl KO mouse is generated by insertion of a neomycin cassette in exon 5 , resulting in a lack of production of FMRP (c). NLS and NES domains allow FMRP to enter and exit the nucleus to bind and transport mRNAs. FMRP is a protein with multiple sites of interaction with mRNAs such as $\mathrm{KH}$ and RGG domains with differential affinity to mRNAs. thesis at the synapse $[17,18]$. All of these studies have consistently shown that one major function of FMRP is to regulate the translation of many genes at the synapse, typically acting as a negative modulator of synaptic strength, and as a result FXS is considered a disorder of synaptic function (fig. 2). Numerous studies revealed that FMRP is normally produced in response to activation of group 1 metabotropic glutamate receptors (mGluR) [19]. This was a key finding that established the roots for the 'mGluR theory', which posits that disrupted metabotropic glutamate receptor 5 (mGluR5) synaptic plasticity is central to the FXS phenotype. This hypothesis has received significant support from several studies in the cerebral cortex and hippocampus in the Fmrl KO mouse [20]. For example, many aspects of the Fmrl KO mouse phenotype can be genetically rescued by mGluR 5 knockdown [21] as well as with pharmacological blockade of mGluR5 receptors [22, 23]. Collectively, these studies have led to novel therapeutic approaches for FXS that pharmacologically target mGluR signaling.

Interestingly, findings to date indicate that certain brain regions are differentially sensitive to the impact 
Fig. 2. FMRP is expressed in the amygdala and influences fear and stress response. FMRP is present at the synapse and regulates the translation of numerous proteins important for synaptic structure and function. Absence of FMRP at the synapse affects amygdala circuit function and therefore ultimately behavior.

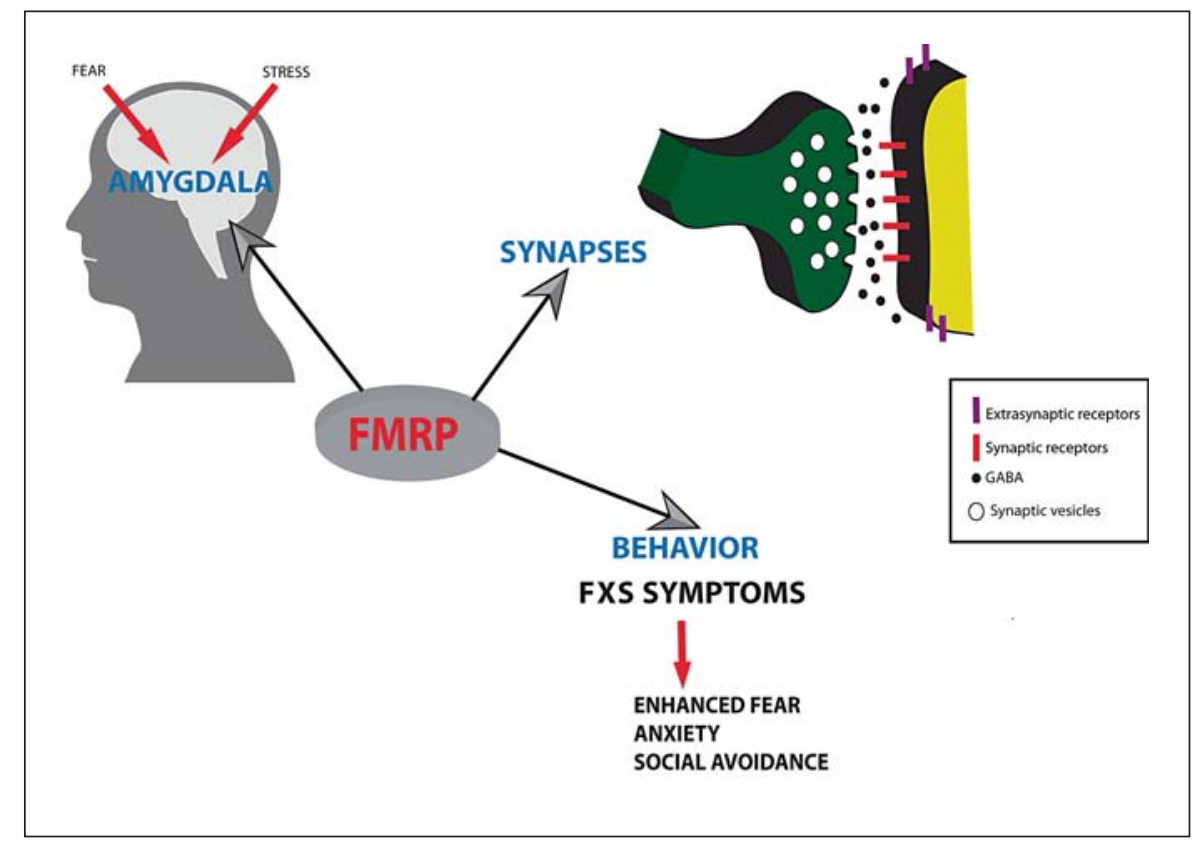

of FMRP loss relative to others, and the maturational period(s) during which FMRP plays a critical role in brain development may differ from region to region (reviewed in Hoeft et al. [24]). This idea is important since the vast majority of studies in Fmrl KO mice have been conducted in the cerebral cortex and hippocampus in contrast to lesser studied regions such as the amygdala or the caudate nucleus, two regions which are also thought to have a primary role in the major behavioral abnormalities observed in FXS [25]. As mentioned above, FXS in humans is accompanied by a number of behavioral/emotional abnormalities such as increased anxiety, aggressiveness, stress, and fearfulness, all of which very strongly affect the daily life of persons with FXS and their families. Currently, there is consensus in the field that the amygdala is a key brain structure involved in complex emotional responses such as fear, anxiety, stress, and aggression within social and nonsocial behavioral contexts, as well as in the acquisition and storage of innate and acquired fear memories [26]. People who suffer amygdala damage undergo profound changes in their emotional and social responses, and thus, to gain a more complete picture of the pathogenesis of FXS, a deeper understanding of amygdala development and circuit function in both normal and FXS animal models is essential for the identification of novel targets for therapeutic intervention.

\section{Emotions: Fear in Mental Health}

Charles Darwin [27], in his book The Expression of Emotions in Man and in Animals published in 1872, appreciated some important key biological underpinnings of human emotional life. He emphasized that emotions are universally shared by animals and humans and are part of a basic avoidance system designed to enhance feeling 'good' and decrease feeling 'bad'. He also argued that emotions have a social factor, are important in mate selection, and are communicated by facial expression. Almost 140 years after the publication of Charles Darwin's seminal book, neuroscientists worldwide agree with the notion that emotional circuits influence communication, intellectual skills and decision-making, and that proper functioning of these circuits is also important to maintain physical and mental health. Indeed, it is also thought that abnormalities in the detection, response and interpretation of emotions such as fear are fundamental to many forms of psychopathology (reviewed in Monk [28]).

The emotional action program we call fear is a response to a potentially dangerous event in our life, allowing animals and human beings to defend themselves from physical or (in the case of higher animals) emotional harm. Fear is categorized as a negative emotion with high levels of arousal in contrast with the negative emotion sadness with low levels of arousal. Fear is considered an ancient evolutionary emotion because of its success in 
protecting animals from danger, therefore, it is essential for the survival of a given species. Thus, arguably fear may have a stronger influence on us in our daily life, much more than positive emotions such as happiness or reward.

Normal fear exists in two major forms: innate or automatic fear, which is built into the organism as a response to external or internal danger, and is under more rigid genetic control, and learned fear, to which an organism may be genetically predisposed but which is basically acquired through experience. Since any capability that enhances survival tends to be conserved through evolution, both innate and learned fear are conserved throughout the animal kingdom. While fear to certain kinds of stimuli are innately hardwired (e.g. a loud noise evoking fear in newborns), fear can also be learned rapidly and lastingly to different stimuli, which allows animals to respond adaptively to new or changing environmental situations. Pathological conditions in the individual appear when innate fear is excessive and persistent, enough to paralyze action, or when learned fear is provoked by events that present no real threat for the individual [29]. Indeed, dysfunction or dysregulation of circuits that regulate fear behavior is thought to underlie a host of anxiety disorders in humans, including posttraumatic stress disorder, panic disorder and agoraphobia, obsessive-compulsive disorder, and social anxiety disorder [30]. Interestingly, anxiety is a core problem in FXS that can manifest in different ways and may even show in the first years of life [31,32]. Typically, this is seen as exaggerated separation anxiety, with the child becoming panicked whenever the parents are far away [33]. In addition, individuals with FXS, although typically quite friendly, are often abnormally shy. For example, one of the major characteristics of males with FXS is the 'fragile X handshake', where the individual averts his gaze and turns his body away while offering his hand to another. The desire for social contact seems to be strong, but the demands of greeting while visually engaged in the partner appear to be overwhelming. Another interesting observation with regard to higher-functioning persons with FXS is social anxiety disorder; typically, they may have excessive worries or fear about their competence, performance, and acceptability in a social context, and yet they have enough cognitive awareness to know that they are different, with their anxiety sometimes manifesting in self-deprecating comments (http://www.fragilex.org/html/behavior. htm). As much work has shown that normal social interaction during childhood is necessary to develop language, cognition and attention [34], it is also intriguing to think how an enhanced level of fear/anxiety in children with FXS could negatively impact normal developmental progression.

In addition, it is also important to mention the effects of stress on the fear system as it has been previously described [35]. Stress activates adaptive responses allowing the body to regain its normal equilibrium once the stress has passed [36]. This adaptive response is mainly reached through activation of the autonomic nervous system and the limbic-hypothalamic-pituitary-adrenal axis, which controls the release of a number of stress hormones like cortisol, adrenalin, corticotropin-releasing hormone, and adrenocorticotropic hormone [36]. Dysregulation of this system can lead to persistent over- or underaroused states. Anatomically, the amygdala is a central region in this circuitry. It receives sensory inputs from diverse areas of the brain (e.g. the thalamus, neocortex, olfactory cortex, hippocampus) and sends projections to various autonomic and somatomotor structures believed to mediate specific fear responses (e.g. bed nucleus of the stria terminalis for activating stress hormones, periaqueductal gray matter for freezing behavior, lateral hypothalamus for sympathetic activation) (reviewed in LeDoux [26]). Interestingly, it has been reported that stress response is abnormal in children with FXS [37-39], and studies in Fmr1 KO mice have shown increased vulnerability to stress or enhanced emotional reactivity [40], and an impaired glucocorticoid negative feedback [41]. Consistent with this, FMRP directly interacts with the mRNA encoding glucocorticoid receptors [42] supporting the idea that its absence leads to dysregulation of the stress response in FXS. The finding that stress hormones can amplify conditioned fear responses has important implications for understanding of fear/anxiety disorders $[43,44]$. Therefore, the combinatorial effect of fear and stress signaling from the environment onto a dysfunctional amygdala, which is central to regulating both fear and stress circuits, may be a root cause for a variety of central behavioral problems in FXS individuals (fig. 2).

\section{Amygdala and Fear in FXS}

Typically using fear conditioning paradigms, a large volume of experimental work, mainly in rodents, has examined the neurocircuitry associated with fear responses (reviewed in LeDoux [26]). Fear conditioning, a type of classical conditioning, is a form of associative learning that was first demonstrated in 1927 by the Russian physiologist Ivan Pavlov [45]. Humans, primates, and many 
lower vertebrates such as rodents, readily acquire conditioned fear reactions via associations between neutral stimuli and aversive events [46]. The Pavlovian conditioning of fear commonly used in rodents results in the formation of a strong association between a neutral conditioned stimulus (auditory tone or light) and an aversive unconditioned stimulus (usually a footshock) during a training session. After training, the conditioned stimulus presented alone is able to trigger fear responses. This fear conditioning paradigm has allowed the extensive experimental examination of the acquisition, response and extinction of fear in animals. As fear responses observed in fear conditioning paradigms closely resemble the characteristic behavioral and physiological symptoms of human pathological fears, it is generally accepted that understanding the biological mechanisms of fear acquisition and extinction has key clinical relevance (reviewed in LeDoux [26]).

Key components of fear circuitry include the amygdala, hippocampus, brain stem, hypothalamus, and prefrontal cortex [47]. Indeed, key findings, such as the central role of amygdaloid nuclei in the acquisition of fear conditioning and expression of fear responses, the involvement of the hippocampus in contextual processing, and the importance of the infralimbic cortex in extinction recall have been replicated across different studies and laboratories [48]. These regions play distinct roles in the various components of fear processing such as the perception of threat or of unconditioned stimuli, the pairing of an unconditioned stimulus and conditioned response (learning/conditioning), the execution of efferent components of fear response, and the modulation of fear responses through potentiation, contextual modulation, or extinction [48]. A large body of evidence from lesion, pharmacological and neurophysiological studies points to the amygdala as the neural system subserving fear conditioning across species, including monkeys and humans [49]. In support of this, amygdala functional connectivity appears to be similar across species $[50,51]$. Consistent with animal studies [52, 53], work in humans supports the central role of the amygdala in fear-related behavior. For example, patients with damage to the amygdala display a selective impairment in the recognition of facial expressions of fear [54] and also exhibit deficits in fear conditioning [55]. Amygdala-damaged patients are also impaired in recalling emotionally influenced memory [56]. Imaging studies show that there is a significantly increased blood flow to the amygdala (as measured by functional MRI) when normal subjects are presented with pictures of fearful faces [57] or are undergoing fear conditioning $[58,59]$. Functional activation of the amyg- dala has also been observed (via positron emission tomography) during free recall of emotional information and gaze monitoring $[60,61]$. Collectively, this is consistent with the view that the amygdala is centrally involved in fear conditioning and/or processing emotional information in all vertebrate species including humans.

FXS behavioral manifestations such as high prevalence of gaze avoidance, anxiety and elevated acute stress are, therefore, also consistent with amygdala dysfunction [25, 62]. Indeed clinical studies have shown that these qualities are more frequently represented in individuals with FXS than in individuals with many other developmental and intellectual disabilities [63]. Despite these extensive behavioral problems suggestive of amygdala dysfunction, the amygdala has been understudied in FXS and in animal models of FXS. However, increasing evidence from human neuroimaging studies as well as cellular and behavioral studies in Fmrl KO mice are starting to reveal the basis of the emotional problems in FXS, including fear and anxiety. As such, amygdala abnormalities in FXS have been shown by structural and functional MRI studies which have established and begun to refine the specific topography of neuroanatomical variation associated with FXS [64]. For example, functional MRI studies have shown that hyperarousal of the insula along with the sensitization of the amygdala is part of an aberrant emotional response to direct gaze in individuals with FXS [65]. Structural brain imaging studies have also found anatomical abnormalities between the amygdala and orbitofrontal cortex in FXS, a brain circuit that participates in the regulation of social behaviors [66]. Consistent with findings in humans, behavioral studies have also demonstrated abnormal social behavior, fear conditioning and anxiety in Fmr1 KO mice [13, 67-69]. Moreover, physiological and cellular studies in Fmrl $\mathrm{KO}$ mice in the amygdala are beginning to unravel potential mechanisms underlying these abnormal behaviors in Fmrl KO mice. For example, Fmr1 KO mice display deficiencies in long-term potentiation, a form of synaptic plasticity essential for fear conditioning, in the lateral nucleus of the amygdala (L) [70, 71]. In addition, our recent study has revealed defects in inhibitory neurotransmission in the basolateral nucleus of the amygdala (BL) [72] that may be linked to amygdalabased behavioral defects described in Fmr1 KO mice [68]. These latter results are also consistent with the hypothesis that the primary dysfunction of FXS, similar to many other neurodevelopmental disorders, lies at the level of the synapse [73-75] and suggests that abnormal amygdala synaptic function (both excitatory and inhibitory) might play a key role in fear and anxiety problems in FXS. 


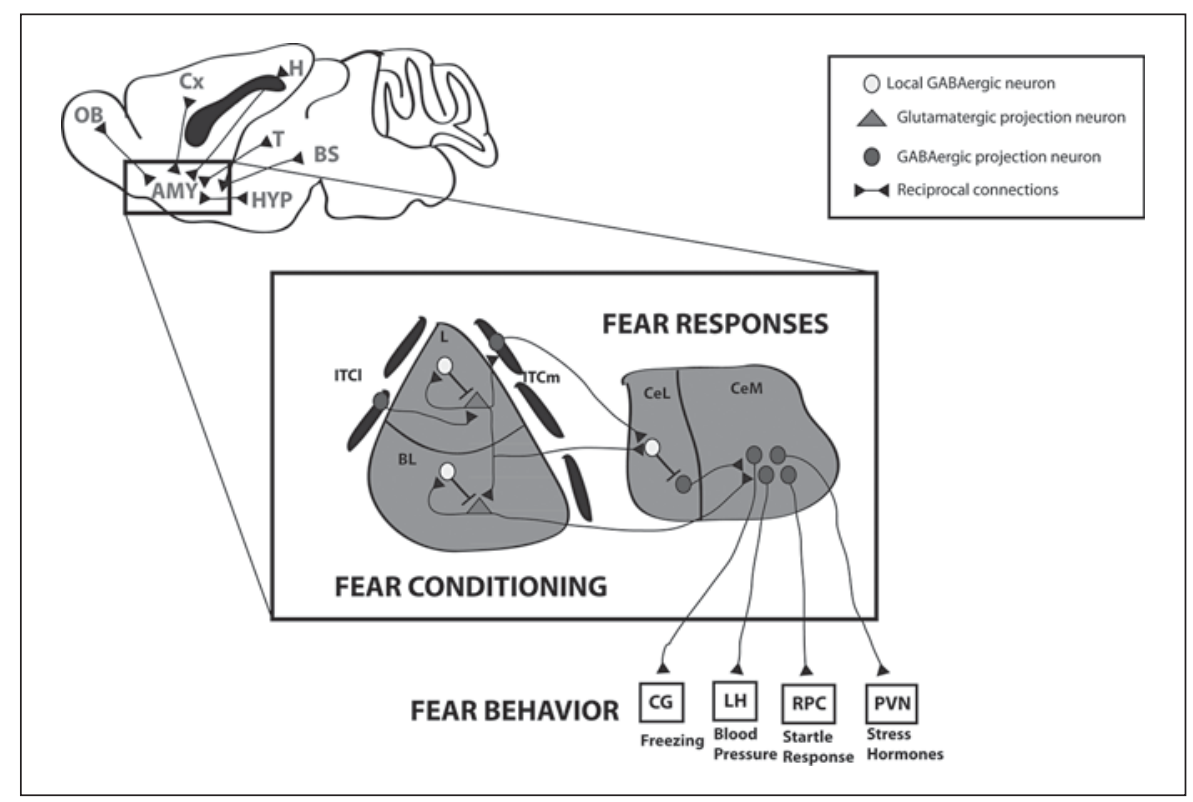

Fig. 3. General scheme of connectivity between the amygdala and associated circuitry, and detailed organization of the flow of information within the amygdaloid complex. In the $\mathrm{L}$ and $\mathrm{BL}$, local interneurons are part of feedforward and feedback circuits that control projection neuron outputs involved in fear conditioning. ITCl and ITCm relay feedforward inhibition to the BL and Ce, respectively. CeM output neurons are under inhibitory control originating in $\mathrm{CeL}$. Intrinsic $\mathrm{CeL}$ inhibition may also participate in controlling CeL output. Ce neurons are mainly involved in processing fear responses by sending out information to different re-

\section{Amygdala Inhibitory Circuits and Fear}

The amygdala is a highly complex heterogeneous structure of the brain. Although it was first anatomically described in the early 19th century [76], much debate still continues today about how the amygdala should be subdivided, and how these subdivisions relate to other major regions of the brain. Despite this uncertainty, it is generally agreed that the amygdala consists of over a dozen, but not more than 15 , functionally distinct subnuclei $[77,78]$. Regardless of the controversy about the exact number of nuclei within the amygdala, both the nuclei and cellular components involved in fear circuitry have been clearly delineated. The L, BL, central nucleus of the amygdala (Ce) as well as specialized subsets of interneurons known as intercalated cell masses (ITC) are the most well-characterized components of the amygdala that are intimately involved in fear memory acquisition, storage and extinction (reviewed in Ehrlich et al. [79]). A general and simplified organization of the amygdala fear circuits de- gions where different outputs of fear behavior are processed. $\mathrm{AMY}=$ Amygdala $\mathrm{BL}=$ basolateral nucleus of the amygdala; $\mathrm{BS}=$ brain stem; $\mathrm{CeL}=$ laterocapsular subdivision of the central amygdala; $\mathrm{CeM}=$ medial subdivision of the central amygdala; $\mathrm{Cx}=$ cerebral cortex; $\mathrm{OB}=$ olfactory bulb; $\mathrm{CG}=$ central gray; $\mathrm{ITCm}=$ medial intercalated cell cluster; $\mathrm{ITCl}=$ lateral intercalated cell cluster; $\mathrm{H}=$ hippocampus; $\mathrm{HYP}=$ hypothalamus; $\mathrm{L}=$ lateral nucleus of the amygdala; $\mathrm{LH}=$ lateral hypothalamus; $\mathrm{RPC}=$ reticulopontis caudalis; $\mathrm{T}=$ thalamus; $\mathrm{PVN}=$ paraven tricular nucleus. pict the L (mainly the dorsolateral part) serving as the major sensory input, mainly from the thalamus and cortex $[77,80,81]$, the BL serving as a storage for fear memories [82], and the Ce (including lateral and mainly medial part) as the major output to different structures in the brain stem and in the hypothalamus to generate autonomic and fear responses [83-86] (fig. 3). Nevertheless, inter- and intranuclear connections, mainly involving the ITC, between these nuclei suggest that information can be processed both by mechanisms intrinsic to amygdala networks as well as modified by interactions within other brain structures to integrate sensory inputs, generate fear response outputs, and modulate fear responses according to the environment (reviewed in LeDoux [26]) (fig. 3). An intriguing and important aspect of this nuclear circuit organization is that it combines 'cortex-like' and 'striatum-like' structures. Although this is an oversimplification as the individual output neurons may have different developmental origins and perform different functions, it provides a simple framework in which to 
conceptualize amygdala circuit organization. In this scheme, the L and BL are considered 'cortical-like' structures, as their output neurons are glutamatergic projection neurons [87]. In contrast, the Ce is 'striatal-like', as its output neurons are GABAergic projection neurons which exhibit medium spiny-type morphology [88]. Importantly, synapsing upon each type of output neuron exist a variety of functionally diverse inhibitory interneurons, in addition to the ITC, that predominantly includes interneurons that express the calcium-binding protein parvalbumin (PV), which are essential for modulating both synaptic and circuit function.

The importance of amygdala inhibitory circuits as a major determinant of amygdala activity is increasingly being revealed, especially in the $\mathrm{L}$ and $\mathrm{BL}$, and several lines of animal research support that deficient inhibitory tone in the amygdala could lead to overexpression of conditioned fear responses, producing pathological states such as anxiety/fear disorders and drug-seeking behavior [89]. One major role of inhibition in the amygdala is to exert a powerful regulatory inhibitory control of the excitability of glutamatergic neurons in the amygdala, which, compared to the cerebral cortex, have remarkably lower firing rates [90]. In addition, rhythmic oscillations in the BL, which are hypothesized to underlie amygdalabased behaviors, are dependent on PV+ interneuronal subclasses [91, 92]. Indeed, this PV network is thought to play a role in the generation of emotional arousal [91]. Moreover, much recent work has implicated the ITC as being centrally involved in mediating both incoming communication from the cerebral cortex and outputs to the Ce [93-95]. Additional evidence also supports the notion that inhibition within the amygdala plays a central role in gating pre- and postsynaptic plasticity in the $\mathrm{L}$, and therefore in fear-related behaviors [79]. Most strikingly, enhancing GABAergic transmission can interfere with the acquisition or expression of conditioned fear responses and with the acquisition of extinction [96-98]. In contrast, decreasing GABAergic transmission can improve learning or retrieval of conditioned fear memories and impairs extinction memory retrieval in a contextspecific manner $[97,99]$. Thus, interneurons may act as gating the processing of different aspects of fear conditioning and extinction within the amygdala. Collectively, these studies strongly suggest that adequate levels of inhibition may be required to prevent expression of emotional association at inappropriate times or contexts when the signal does not indicate danger. Failure in this inhibitory control mechanism can lead to overexpression of conditioned associations, which could appear as the pathological states we know as fear/anxiety disorders and other pathologies.

Interneurons comprise about $20 \%$ of the L and BL neurons [100]. At this moment, we have a fairly good knowledge of the diversity of interneurons in the $\mathrm{BL}$, comprising several major subtypes that can be differentially identified by expression of the molecular markers PV, somatostatin, cholecystokinin, calbindin, calretinin, and vasoactive intestinal peptide [100-104]. Previous studies suggest that the influence of GABAergic interneurons on excitatory cells is largely dependent on the subcellular location of their inputs, which varies among different interneuron subtypes (reviewed in Gelman and Marin [105]). In the BL, PV+ neurons make up the largest subgroup of interneurons (about 50\%), and a substantial portion are fast-spiking cells that target the soma and proximal dendrites of projection neurons and possibly the axon initial segment $[106,107]$. In addition, PV+ neurons are probably part of both feedback [108] and feedforward inhibitory circuits [109]. At the circuit level, feedforward and feedback inhibition is observed in the BL [110] and as we noted earlier, PV network is an intriguing candidate to regulate rhythmic oscillations in the BL during emotional arousal [91]. In contrast, somatostatin-positive interneurons contact mostly distal dendrites and spines of $\mathrm{BL}$ projection neurons [111], suggesting that they may interact with and affect plasticity at distal inputs. In the L, it is unclear if and which specific interneuron subtypes can be assigned to these tasks [112]. Fast-spiking interneurons have been identified to receive converging thalamic and cortical sensory input and mediate GABAergic feedforward inhibition which tightly controls the activity of projection neurons [113-115] making them good candidates for participating in gating of sensory afferent longterm potentiation. Intriguingly, a recent study has provided evidence that fear memories are not evenly stored in neuronal networks in the L [116]. This study shows that the activity of the transcription factor CREB (cyclic adenosine $3^{\prime}, 5^{\prime}$-monophosphate response element binding protein) is involved in determining which subset of neurons are recruited for storing fear memories. Interestingly, the authors of this work also suggest that activity of inhibitory circuits might delimit the number of neurons committed to any one given memory. How these circuits are preselected for potentiation is unknown, but one intriguing possibility is that they may be 'prepatterned' (specified) during developmental stages of amygdala formation.

In addition to the involvement of classical neurotransmitter molecules, neuromodulatory systems in the amyg- 
dala appear to be involved in fear conditioning [117], with inhibitory neurons being major targets of these neuromodulatory systems $[118,119]$. One such molecule implicated in this circuitry is gastrin-related peptide receptor, which is highly expressed in GABAergic interneurons of the L. It appears that gastrin-related peptide, which is released as a cotransmitter with glutamate in excitatory cells, activates interneurons, which results in increases in inhibition onto excitatory cells [120]. In addition, it has been shown that the known behavioral neuromodulators oxytocin and vasopressin and their receptors, which play a central role in the integration of emotional states [121], are expressed in specific subpopulations of GABAergic neurons in the Ce. Interestingly, chronic or genetic disruptions in the vasopressin or oxytocin system could have consequences for autonomic function contributing to behavioral changes associated with increased anxiety and abnormal fear $[122,123]$. Therefore, understanding the mechanism that controls the expression of emotional associations in the amygdala, and specifically the intricate inhibitory networks that regulate circuit function in the amygdala, appears to be essential for advancing therapies for the amygdala in FXS.

\section{Targeting the GABAergic System in FXS}

Important and unexpected recent findings from several different animal models of developmental disorders, including animal models of FXS, suggest that it is possible to reverse the symptoms of certain neurodevelopmental disorders in adults. For example, it has been reported that a brief rapamycin treatment in adult $T s c 2^{+/-}$mutant mice, an animal model of the neurodevelopmental disorder tuberous sclerosis, rescued not only brain physiological abnormalities, but quite strikingly, learning and memory deficits [124]. In addition, as mentioned earlier, pharmacological and genetic studies towards decreasing mGluR5 signaling have proven to correct many abnormalities in Fmrl KO mice [21-23]. Not surprisingly, considering the key role of FMRP in neuronal communication and synaptic function, a number of studies have demonstrated dysfunction of the GABAergic system in Fmr1 KO mice as well. For example, alterations in the expression of several important presynaptic and postsynaptic components of the inhibitory transmission machinery, including $\mathrm{GABA}_{\mathrm{A}}$ receptor subunits, GABA transporters, GAD, and gephyrin in Fmr1 KO mice have been consistently observed [72, 125-129]. Interestingly, the absence of FMRP has distinct effects on GABAergic circuit function in different brain regions. For example, reductions in the number and altered activity of PV+ inhibitory neurons have been demonstrated in the somatosensory cortex but not in the hippocampus of Fmrl KO mice $[130,131]$, suggesting a region-dependent defect in inhibitory neuronal genesis, migration and/or survival. In addition, in stark contrast to decreased GABAergic transmission in the amygdala [72], studies in the striatum have revealed increased GABAergic neurotransmission in Fmrl KO mice [132]. Thus, mechanisms that result in alterations in inhibitory drive in the amygdala may involve, at least in part, different processes than in the cerebral cortex and striatum. As mounting evidence of GABAergic dysfunction in Fmrl KO mice is being reported, it is increasingly evident that inhibitory GABAergic transmission is an intriguing target for the treatment of FXS. Consistent with this, previous data have shown that the most efficacious treatments in the drosophila model of FXS modulated GABAergic signaling [133]. In addition, it has been reported that taurine, a $\mathrm{GABA}_{\mathrm{A}}$ receptor agonist, has been shown to improve cognitive functions in the Fmr1 KO mouse [134]. Moreover, our recent work in the BL demonstrated that enhancing GABAergic transmission in brain slices using THIP, a superagonist at $\mathrm{GABA}_{\mathrm{A}} \delta$ subunit-containing perisynaptic and extrasynaptic $\mathrm{GABA}_{\mathrm{A}}$ receptors [135-137], rescued the abnormal firing rate of projection neurons in Fmrl $\mathrm{KO}$ mice [72]. Of the GABAergic machinery, the underexpression of the $\delta$ subunit has been found to be the most significant among all subunits of the $\mathrm{GABA}_{\mathrm{A}}$ receptors [128]. As FMRP binds the mRNA encoding the $\delta$ subunit of the $\mathrm{GABA}_{\mathrm{A}}$ receptor [42], this may be one direct mechanism underlying GABAergic dysfunction, and therefore, enhancing GABAergic transmission, specifically via tonic inhibition, might be a novel and reliable target to ameliorate or cure some symptoms in FXS.

\section{Developmental Studies of Amygdala Fear Circuits: Importance for FXS}

As neurons and their synapses are the building blocks of behavior, studies focusing on how neurons are specified, proliferate, migrate and form functional circuits during development are critical to understand brain function in both normal and abnormal conditions. Developing neurons are very sensitive to genetic and environmental perturbations, and subtle and selective disruptions in the assembly of an early neuronal circuit may lead to longlasting consequences in the adult brain. Indeed, increas- 
ing lines of evidence suggest that insults to embryonic brain during development are sufficient to produce a disease process [138]. For example, a study in a mouse model of Down syndrome has recently shown that increased gene dosage of the transcription factors Olig1 and Olig2 in the ventral telencephalon during embryonic development is responsible for the increased number of certain subtypes of interneurons in the postnatal cerebral cortex and hippocampus [139]. This overproduction of interneurons results in overinhibition in both brain regions postnatally, and may be an underlying causative factor, or contribute to the phenotype of Down syndrome. This finding is also consistent with the current view that excitation-inhibition imbalances are thought to be a major component of several other neurodevelopmental disorders, including FXS $[73-75,140]$. Since this excitation-inhibition imbalance is thought to be caused by altered synaptic function, the known role that FMRP plays in synaptic development (e.g. axon guidance), formation of synapses and synaptic function and plasticity emphasizes the importance of this protein in key brain functions (reviewed in Bassell and Warren [14]). Thus, it is reasonable to think that the lack of FMRP during neural development results in altered amygdala circuits and suggests that further studies identifying the developmental mechanisms of amygdala development might be informative for understanding some behavioral problems in FXS associated with the amygdala such as fear and anxiety (fig. 3).

Although embryonic development of the amygdala is poorly understood, a wide array of approaches used in a number of studies, including fate mapping, migration assays and genetic knockout studies, are assembling an interesting picture specifically regarding the development of the fear circuits in the amygdala [141-144]. Several transcription factors and genes are thought to be involved in regulating amygdala development and function, so any disruption of the function of one or more of these genes during development might impair the appropriate functional ensembles of neurons and synapses, which ultimately mediate fear and anxiety behaviors. In terms of neuronal specification, studies have revealed that neuronal diversity in the amygdala is generated from multiple embryonic progenitor pools, some of which may be solely dedicated to the amygdala [141-144]. For example, genetic fate mapping of the progeny of progenitors that express several transcription factors, including Isll, DbxI and $P a x 6$, generates subclasses of neurons within the fear circuit. For example, Isl1-positive progenitors give rise to neurons in the medial subdivision of the Ce [143], a subregion recently shown to be necessary and sufficient for driving freezing behavior [145]. Moreover, Dbx1- and Pax6-derived progenitors specifically generate subpopulations of amygdala neurons dedicated to either innate or fear-related behaviors $[143,144,146]$. Advances in these basic developmental studies focusing on the formation and function of fear circuits in the amygdala may inform about critical aspects of amygdala formation in multiple neurodevelopmental disorders, including FXS.

Thus, the amygdala appears to have a critical role in a defining moment for brain function; the transition from late embryonic to early postnatal life. During this time, neurons previously unconnected become plugged into circuits through a dynamic process of synapse formation, stabilization, and elimination reflecting neuronal activity. At the same time, they must homeostatically maintain the delicate excitatory-inhibitory balance required for nascent network function. This early maturation of this circuitry puts the amygdala as a key orchestrator of emotional experience during development of the emotional system of the infant brain. Moreover, children with FXS can show behavioral abnormalities at very young ages, suggesting that amygdala circuitry might already be dysfunctional by the time the child is born, or might be impaired due to the inability of the amygdala circuitry to encounter and correctly process environmental information, ultimately resulting in behavioral problems. Thus, it is intriguing to wonder how early abnormalities in these evolutionary old systems of the brain such as the amygdala could drive alterations in higher-order regions of an infant brain. In this line of thinking, it has been argued that human brain development is a tremendously rich cascade of genetic checkpoints and environmental shaping, designed to build more and more complex stages, each advance depending on the last [147]. The foundation or early stages of the brain would involve sensory areas dedicated primarily to attend the needs of the body and the survival of the individual [148], and the amygdala is one of those key areas as a monitor of the environment early in infant development.

\section{Conclusions}

As stated by others [138], one of the main goals of basic scientific exploration is to understand and treat human disorders. With regard to FXS, multiple lines of basic research combined with clinical research has led to a deeper understanding of the role of the amygdala, and inhibitory neurons [see also review by Paluszkiewicz et al., this issue], in the deficits specifically associated with this disorder. This research has delineated that both the amyg- 
dala and the GABAergic system are key targets of this disorder. Consistent with this, as GABA receptors are involved in anxiety, fear, and stress responses (reviewed in Deutsch et al. [149] and Domschke and Zwanzger [150]), features disturbed in FXS, dysfunction of the GABAergic system and specifically in the amygdala, would appear to have highly relevant physiological, cellular and functional consequences that relate to the behavioral phenotype associated with FXS. In support of this are the recent very promising phase II clinical trials in FXS, which indicate that GABA receptor agonists such as R-baclofen (STX209, Seaside Therapeutics) have a positive outcome for amygdala-based symptoms such as social avoidance. Currently, we are entering a new age of targeted treatments for FXS and more widespread screening for this disorder. As targeted treatments to reverse FXS symptoms are being studied in patients, as well as in continuous development, there is reason to be optimistic about the discovery of ef- fective treatments. Since lack of FMRP appears to affect different brain regions in a different manner, it is plausible to envision that treatments in FXS will employ targeted pharmacological 'cocktails', combining, for example, specific GABA receptor agonists or antagonists and mGluR5 antagonists. Thus, although the wide range of behavioral abnormalities in FXS make this a complicated puzzle to solve, toward this aim, specific targeting of the dysfunction associated with the amygdala 'fear' system may have broad-ranging positive outcomes.

\section{Acknowledgements}

This work was supported by grants from the following institutions to J.G.C.: US National Institute on Drug Abuse, the Hazeltine Foundation, the CNMC Neurodevelopment Disorders Fund, the FRAXA Research Foundation, and Autism Speaks.

\section{References}

1 Martin JP, Bell J: A pedigree of mental defect showing sex linkage. J Neurol Psychiatry 1943;6:154-157.

2 Lubs HA: A marker X chromosome. Am J Hum Genet 1969;21:231-244.

3 Sutherland GR: Fragile sites on human chromosomes: demonstration of their dependence on the type of tissue culture medium. Science 1977;197:265-266.

4 Hagerman RJ: Lessons from fragile X regarding neurobiology, autism, and neurodegeneration. J Dev Behav Pediatr 2006;27:63-74.

$\checkmark 5$ Hall SS, Lightbody AA, Hirt M, Rezvani A, Reiss AL: Autism in fragile X syndrome: a category mistake? J Am Acad Child Adolesc Psychiatry 2010;49:921-933.

-6 Verkerk AJ, Pieretti M, Sutcliffe JS, Fu YH, Kuhl DP, Pizzuti A, Reiner O, Richards S, Victoria MF, Zhang FP, et al: Identification of a gene (FMR-1) containing a CGG repeat coincident with a breakpoint cluster region exhibiting length variation in fragile $\mathrm{X}$ syndrome. Cell 1991;65:905-914.

-7 Abitbol M, Menini C, Delezoide AL, Rhyner T, Vekemans M, Mallet J: Nucleus basalis magnocellularis and hippocampus are the major sites of FMR-1 expression in the human fetal brain. Nat Genet 1993;4:147-153.

8 Ashley CT Jr, Wilkinson KD, Reines D, Warren ST: FMR1 protein: Conserved RNP family domains and selective RNA binding. Science 1993;262:563-566.
9 Devys D, Lutz Y, Rouyer N, Bellocq JP, Mandel JL: The FMR-1 protein is cytoplasmic, most abundant in neurons and appears nor$\mathrm{mal}$ in carriers of a fragile $\mathrm{X}$ premutation. Nat Genet 1993;4:335-340.

10 Zhang Y, O’Connor JP, Siomi MC, Srinivasan S, Dutra A, Nussbaum RL, Dreyfuss G: The fragile $\mathrm{X}$ mental retardation syndrome protein interacts with novel homologs FXR1 and FXR2. EMBO J 1995; 14:5358-5366.

11 Warter JM, Tranchant C: Hereditary neurological diseases caused by amplification of triplet repetitions. Presse Med 1998;27:376381.

12 Fmrl knockout mice: a model to study fragile $\mathrm{X}$ mental retardation. The Dutch-Belgian Fragile X Consortium. Cell 1994;78:23-33.

$\checkmark 13$ Boyle L, Kaufmann WE: The behavioral phenotype of FMR1 mutations. Am J Med Genet C Semin Med Genet 2010;154C:469-476.

14 Bassell GJ, Warren ST: Fragile X syndrome: loss of local mRNA regulation alters synaptic development and function. Neuron 2008; 60: 201-214.

15 Feng Y, Absher D, Eberhart DE, Brown V, Malter HE, Warren ST: FMRP associates with polyribosomes as an mRNP, and the I304N mutation of severe fragile $\mathrm{X}$ syndrome abolishes this association. Mol Cell 1997;1: 109-118.

16 Khandjian EW, Huot ME, Tremblay S, Davidovic L, Mazroui R, Bardoni B: Biochemical evidence for the association of fragile $\mathrm{X}$ mental retardation protein with brain polyribosomal ribonucleoparticles. Proc Natl Acad Sci USA 2004;101:13357-13362.
17 Laggerbauer B, Ostareck D, Keidel EM, Ostareck-Lederer A, Fischer U: Evidence that fragile $\mathrm{X}$ mental retardation protein is a negative regulator of translation. Hum Mol Genet 2001;10:329-338.

18 Li Z, Zhang Y, Ku L, Wilkinson KD, Warren ST, Feng Y: The fragile X mental retardation protein inhibits translation via interacting with mRNA. Nucleic Acids Res 2001;29: 2276-2283.

19 Weiler IJ, Irwin SA, Klintsova AY, Spencer $\mathrm{CM}$, Brazelton AD, Miyashiro K, Comery TA, Patel B, Eberwine J, Greenough WT: Fragile $\mathrm{X}$ mental retardation protein is translated near synapses in response to neurotransmitter activation. Proc Natl Acad Sci USA 1997;94:5395-5400.

20 Bear MF, Huber KM, Warren ST: The mGluR theory of fragile $\mathrm{X}$ mental retardation. Trends Neurosci 2004;27:370-377.

21 Dolen G, Osterweil E, Rao BS, Smith GB, Auerbach BD, Chattarji S, Bear MF: Correction of fragile $\mathrm{X}$ syndrome in mice. Neuron 2007;56:955-962.

22 McBride SM, Choi CH, Wang Y, Liebelt D, Braunstein E, Ferreiro D, Sehgal A, Siwicki KK, Dockendorff TC, Nguyen HT, McDonald TV, Jongens TA: Pharmacological rescue of synaptic plasticity, courtship behavior, and mushroom body defects in a Drosophila model of fragile X syndrome. Neuron 2005; 45:753-764. 
-23 Yan QJ, Rammal M, Tranfaglia M, Bauchwitz RP: Suppression of two major fragile $\mathrm{X}$ syndrome mouse model phenotypes by the mGluR5 antagonist MPEP. Neuropharmacology 2005;49:1053-1066.

24 Hoeft F, Carter JC, Lightbody AA, Cody Hazlett H, Piven J, Reiss AL: Region-specific alterations in brain development in one- to three-year-old boys with fragile X syndrome. Proc Natl Acad Sci USA 2010;107:9335-9339.

$\checkmark 25$ Hessl D, Rivera SM, Reiss AL: The neuroanatomy and neuroendocrinology of fragile X syndrome. Ment Retard Dev Disabil Res Rev 2004;10:17-24.

26 LeDoux J: The emotional brain, fear, and the amygdala. Cell Mol Neurobiol 2003;23:727738.

27 Darwin C: The expression of emotions in man and animals. London, Murray, 1872.

28 Monk CS: The development of emotion-related neural circuitry in health and psychopathology. Dev Psychopathol 2008;20:12311250.

-29 Rosen JB, Schulkin J: From normal fear to pathological anxiety. Psychol Rev 1998;105: 325-350.

-30 Davis M: The role of the amygdala in fear and anxiety. Annu Rev Neurosci 1992;15:353375.

- 31 Bailey DB Jr, Raspa M, Olmsted M, Holiday DB: Co-occurring conditions associated with FMR1 gene variations: findings from a national parent survey. Am J Med Genet A 2008;146A:2060-2069.

- 32 Cordeiro L, Ballinger E, Hagerman R, Hessl D: Clinical assessment of DSM-IV anxiety disorders in fragile $\mathrm{X}$ syndrome: prevalence and characterization. J Neurodev Disord 2011;3:57-67.

33 Tranfaglia M: Medication Guide for Fragile X Syndrome. FRAXA Research Foundation, 2009.

34 Kuhl PK: Brain mechanisms in early language acquisition. Neuron 2010;67:713-727.

- 35 Jacobs WJ, Nadel L: Stress-induced recovery of fears and phobias. Psychol Rev 1985;92: 512-531.

36 McEwen BS, Gianaros PJ: Stress- and allostasis-induced brain plasticity. Annu Rev Med 2011;62:431-445.

- 37 Hessl D, Glaser B, Dyer-Friedman J, Blasey C, Hastie T, Gunnar M, Reiss AL: Cortisol and behavior in fragile $\mathrm{X}$ syndrome. Psychoneuroendocrinology 2002;27:855-872.

- 38 Hessl D, Glaser B, Dyer-Friedman J, Reiss AL: Social behavior and cortisol reactivity in children with fragile X syndrome. J Child Psychol Psychiatry 2006;47:602-610.

-39 Wisbeck JM, Huffman LC, Freund L, Gunnar MR, Davis EP, Reiss AL: Cortisol and social stressors in children with fragile X: a pilot study. J Dev Behav Pediatr 2000;21:278-282.

-40 Nielsen DM, Evans JJ, Derber WJ, Johnston KA, Laudenslager ML, Crnic LS, Maclean $\mathrm{KN}$ : Mouse model of fragile X syndrome: behavioral and hormonal response to stressors. Behav Neurosci 2009;123:677-686.
41 Markham JA, Beckel-Mitchener AC, Estrada CM, Greenough WT: Corticosterone response to acute stress in a mouse model of fragile X syndrome. Psychoneuroendocrinology 2006;31:781-785.

42 Miyashiro KY, Beckel-Mitchener A, Purk TP, Becker KG, Barret T, Liu L, Carbonetto S, Weiler IJ, Greenough WT, Eberwine J: RNA cargoes associating with FMRP reveal deficits in cellular functioning in FMR1 null mice. Neuron 2003;37:417-431.

43 Ledoux J: The Emotional Brain. New York, Simon and Schuster Paperbacks, 1996, pp 247.

44 Conrad CD, LeDoux JE, Magarinos AM, McEwen BS: Repeated restraint stress facilitates fear conditioning independently of causing hippocampal CA3 dendritic atrophy. Behav Neurosci 1999;113:902-913.

45 Pavlov IP: Conditioned Reflexes: An Investigation of the Physiological Activity of the Cerebral Cortex (translated and edited by GV Anrep). London, Oxford University Press, 1927.

46 LeDoux J: Emotional networks and motor control: a fearful view. Prog Brain Res 1996; 107:437-446.

47 Davis M: Neural systems involved in fear and anxiety measured with fear-potentiated startle. Am Psychol 2006;61:741-756.

48 Kim JJ, Jung MW: Neural circuits and mechanisms involved in Pavlovian fear conditioning: a critical review. Neurosci Biobehav Rev 2006;30:188-202.

49 Shin LM, Liberzon I: The neurocircuitry of fear, stress, and anxiety disorders. Neuropsychopharmacology 2010;35:169-191.

50 Amaral DG, Price JL: Amygdalo-cortical projections in the monkey (Macaca fascicularis). J Comp Neurol 1984;230:465-496.

51 Pitkanen A, Pikkarainen M, Nurminen N, Ylinen A: Reciprocal connections between the amygdala and the hippocampal formation, perirhinal cortex, and postrhinal cortex in rat. A review. Ann NY Acad Sci 2000; 911:369-391.

52 Blanchard DC, Blanchard RJ: Innate and conditioned reactions to threat in rats with amygdaloid lesions. J Comp Physiol Psychol 1972;81:281-290.

53 Klüver H, Bucy PC: 'Psychic blindness' and other symptoms following bilateral temporal lobectomy in rhesus monkeys. Am J Physiol 1937;119:352-353.

54 Adolphs R, Tranel D, Damasio H, Damasio A: Impaired recognition of emotion in facial expressions following bilateral damage to the human amygdala. Nature 1994;372:669672.

55 LaBar KS, LeDoux JE, Spencer DD, Phelps EA: Impaired fear conditioning following unilateral temporal lobectomy in humans. J Neurosci 1995; 15:6846-6855.

56 Cahill L, Babinsky R, Markowitsch HJ, McGaugh JL: The amygdala and emotional memory. Nature 1995;377:295-296.
57 Morris JS, Frith CD, Perrett DI, Rowland D, Young AW, Calder AJ, Dolan RJ: A differential neural response in the human amygdala to fearful and happy facial expressions. $\mathrm{Na}$ ture 1996;383:812-815.

58 Knight DC, Smith CN, Stein EA, Helmstetter FJ: Functional MRI of human Pavlovian fear conditioning: patterns of activation as a function of learning. Neuroreport 1999;10: 3665-3670.

59 LaBar KS, Gatenby JC, Gore JC, LeDoux JE, Phelps EA: Human amygdala activation during conditioned fear acquisition and extinction: a mixed-trial fMRI study. Neuron 1998; 20:937-945.

60 Cahill L, Haier RJ, Fallon J, Alkire MT, Tang C, Keator D, Wu J, McGaugh JL: Amygdala activity at encoding correlated with longterm, free recall of emotional information. Proc Natl Acad Sci USA 1996;93:8016-8021.

61 Kawashima R, Sugiura M, Kato T, Nakamura A, Hatano K, Ito K, Fukuda H, Kojima S, Nakamura $\mathrm{K}$ : The human amygdala plays an important role in gaze monitoring. A PET study. Brain 1999;122:779-783.

62 Budimirovic DB, Bukelis I, Cox C, Gray RM, Tierney E, Kaufmann WE: Autism spectrum disorder in fragile $\mathrm{X}$ syndrome: differential contribution of adaptive socialization and social withdrawal. Am J Med Genet A 2006; 140A:1814-1826.

63 Artigas-Pallares J, Brun-Gasca C: Can the behavioural phenotype of fragile $\mathrm{X}$ syndrome be attributed to mental retardation and to attention deficit hyperactivity disorder? Rev Neurol 2004;38:7-11.

64 Lightbody AA, Reiss AL: Gene, brain, and behavior relationships in fragile $\mathrm{X}$ syndrome: evidence from neuroimaging studies. Dev Disabil Res Rev 2009;15:343-352.

65 Watson C, Hoeft F, Garrett AS, Hall SS, Reiss AL: Aberrant brain activation during gaze processing in boys with fragile $\mathrm{X}$ syndrome. Arch Gen Psychiatry 2008;65:1315-1323.

66 Gothelf D, Furfaro JA, Hoeft F, Eckert MA, Hall SS, O'Hara R, Erba HW, Ringel J, Hayashi KM, Patnaik S, Golianu B, Kraemer HC, Thompson PM, Piven J, Reiss AL: Neuroanatomy of fragile $\mathrm{X}$ syndrome is associated with aberrant behavior and the fragile $\mathrm{X}$ mental retardation protein (FMRP). Ann Neurol 2008;63:40-51.

67 McNaughton $\mathrm{CH}$, Moon J, Strawderman MS, Maclean KN, Evans J, Strupp BJ: Evidence for social anxiety and impaired social cognition in a mouse model of fragile $\mathrm{X}$ syndrome. Behav Neurosci 2008;122:293-300.

68 Paradee W, Melikian HE, Rasmussen DL, Kenneson A, Conn PJ, Warren ST: Fragile X mouse: strain effects of knockout phenotype and evidence suggesting deficient amygdala function. Neuroscience 1999;94:185-192.

-69 Spencer CM, Graham DF, Yuva-Paylor LA, Nelson DL, Paylor R: Social behavior in FMR1 knockout mice carrying a human FMR1 transgene. Behav Neurosci 2008;122: 710-715. 
-70 Suvrathan A, Hoeffer CA, Wong H, Klann E, Chattarji S: Characterization and reversal of synaptic defects in the amygdala in a mouse model of fragile X syndrome. Proc Natl Acad Sci USA 2010;107:11591-11596.

-71 Zhao MG, Toyoda H, Ko SW, Ding HK, Wu LJ, Zhuo M: Deficits in trace fear memory and long-term potentiation in a mouse model for fragile X syndrome. J Neurosci 2005; 25:7385-7392.

72 Olmos-Serrano JL, Paluszkiewicz SM, Martin BS, Kaufmann WE, Corbin JG, Huntsman MM: Defective GABAergic neurotransmission and pharmacological rescue of neuronal hyperexcitability in the amygdala in a mouse model of fragile X syndrome. J Neurosci 2010;30:9929-9938.

-73 Belmonte MK, Allen G, Beckel-Mitchener A, Boulanger LM, Carper RA, Webb SJ: Autism and abnormal development of brain connectivity. J Neurosci 2004;24:9228-9231.

-74 Rubenstein JL, Merzenich MM: Model of autism: increased ratio of excitation/inhibition in key neural systems. Genes Brain Behav 2003;2:255-267.

75 Zoghbi HY: Postnatal neurodevelopmental disorders: meeting at the synapse? Science 2003;302:826-830.

76 Burdach KF: Vom Baue und Leben des Gehirns. Leipzig, 1819-1822.

-77 Pitkanen A, Savander V, LeDoux JE: Organization of intra-amygdaloid circuitries in the rat: an emerging framework for understanding functions of the amygdala. Trends Neurosci 1997;20:517-523.

-78 Puelles L, Kuwana E, Puelles E, Rubenstein JL: Comparison of the mammalian and avian telencephalon from the perspective of gene expression data. Eur J Morphol 1999;37 139-150.

-79 Ehrlich I, Humeau Y, Grenier F, Ciocchi S, Herry C, Luthi A: Amygdala inhibitory circuits and the control of fear memory. Neuron 2009;62:757-771.

80 McDonald AJ: Cortical pathways to the mammalian amygdala. Prog Neurobiol 1998; $55: 257-332$.

-81 Turner BH, Herkenham M: Thalamoamygdaloid projections in the rat: a test of the amygdala's role in sensory processing. J Comp Neurol 1991;313:295-325.

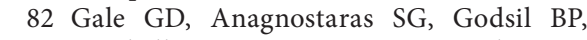
Mitchell S, Nozawa T, Sage JR, Wiltgen B, Fanselow MS: Role of the basolateral amygdala in the storage of fear memories across the adult lifetime of rats. J Neurosci 2004;24: 3810-3815.

83 Krettek JE, Price JL: Amygdaloid projections to subcortical structures within the basal forebrain and brainstem in the rat and cat. J Comp Neurol 1978;178:225-254.

84 LeDoux JE, Iwata J, Cicchetti P, Reis DJ: Different projections of the central amygdaloid nucleus mediate autonomic and behavioral correlates of conditioned fear. J Neurosci 1988;8:2517-2529.
85 Petrovich GD, Swanson LW: Projections from the lateral part of the central amygdalar nucleus to the postulated fear conditioning circuit. Brain Res 1997;763:247-254.

-86 Tsubouchi K, Tsumori T, Yokota S, Okunishi $\mathrm{H}$, Yasui Y: A disynaptic pathway from the central amygdaloid nucleus to the paraventricular hypothalamic nucleus via the parastrial nucleus in the rat. Neurosci Res 2007;59: 390-398.

87 McDonald AJ: Neurons of the lateral and basolateral amygdaloid nuclei: a Golgi study in the rat. J Comp Neurol 1982;212:293-312.

88 McDonald AJ: Cytoarchitecture of the central amygdaloid nucleus of the rat. J Comp Neurol 1982;208:401-418.

89 Quirk GJ, Gehlert DR: Inhibition of the amygdala: key to pathological states? Ann NY Acad Sci 2003;985:263-272.

90 Pare D, Royer S, Smith Y, Lang EJ: Contextual inhibitory gating of impulse traffic in the intra-amygdaloid network. Ann NY Acad Sci 2003;985:78-91.

91 Muller JF, Mascagni F, McDonald AJ: Coupled networks of parvalbumin-immunoreactive interneurons in the rat basolateral amygdala. J Neurosci 2005;25:7366-7376.

92 Pelletier JG, Pare D: Role of amygdala oscillations in the consolidation of emotional memories. Biol Psychiatry 2004;55:559-562.

93 Amano T, Unal CT, Pare D: Synaptic correlates of fear extinction in the amygdala. Nat Neurosci 2010;13:489-494.

94 Busti D, Geracitano R, Whittle N, Dalezios Y, Manko M, Kaufmann W, Satzler K, Singewald N, Capogna M, Ferraguti F: Different fear states engage distinct networks within the intercalated cell clusters of the amygdala. J Neurosci 2011;31:5131-5144.

95 Likhtik E, Popa D, Apergis-Schoute J, Fidacaro GA, Pare D: Amygdala intercalated neurons are required for expression of fear extinction. Nature 2008;454:642-645.

96 Harris JA, Westbrook RF: Effects of benzodiazepine microinjection into the amygdala or periaqueductal gray on the expression of conditioned fear and hypoalgesia in rats. Behav Neurosci 1995;109:295-304.

97 Harris JA, Westbrook RF: Evidence that GABA transmission mediates context-specific extinction of learned fear. Psychopharmacology (Berl) 1998;140:105-115.

98 Hart G, Harris JA, Westbrook RF: Systemic or intra-amygdala injection of a benzodiazepine (midazolam) impairs extinction but spares re-extinction of conditioned fear responses. Learn Mem 2009;16:53-61.

99 Guarraci FA, Frohardt RJ, Young SL, Kapp BS: A functional role for dopamine transmission in the amygdala during conditioned fear. Ann NY Acad Sci 1999;877:732-736.
100 Kemppainen S, Pitkanen A: Distribution of parvalbumin, calretinin, and calbindin$\mathrm{D}(28 \mathrm{k})$ immunoreactivity in the rat amygdaloid complex and colocalization with gamma-aminobutyric acid. J Comp Neurol 2000;426:441-467.

101 Mascagni F, McDonald AJ: Immunohistochemical characterization of cholecystokinin containing neurons in the rat basolateral amygdala. Brain Res 2003;976:171184.

102 McDonald AJ, Mascagni F: Colocalization of calcium-binding proteins and GABA in neurons of the rat basolateral amygdala. Neuroscience 2001;105:681-693.

103 McDonald AJ, Mascagni F: Immunohistochemical characterization of somatostatin containing interneurons in the rat basolateral amygdala. Brain Res 2002;943:237244.

104 Olmos JL, Real MA, Medina L, Guirado S, Davila JC: Distribution of nitric oxide-producing neurons in the developing and adult mouse amygdalar basolateral complex. Brain Res Bull 2005;66:465-469.

105 Gelman DM, Marin O: Generation of interneuron diversity in the mouse cerebral cortex. Eur J Neurosci 2010;31:2136-2141.

106 Muller JF, Mascagni F, McDonald AJ: Pyramidal cells of the rat basolateral amygdala: synaptology and innervation by parvalbumin-immunoreactive interneurons. J Comp Neurol 2006;494:635-650.

107 Rainnie DG, Mania I, Mascagni F, McDonald AJ: Physiological and morphological characterization of parvalbumin-containing interneurons of the rat basolateral amygdala. J Comp Neurol 2006;498:142161.

108 Smith Y, Pare JF, Pare D: Differential innervation of parvalbumin-immunoreactive interneurons of the basolateral amygdaloid complex by cortical and intrinsic inputs. J Comp Neurol 2000;416:496-508.

109 Woodruff AR, Sah P: Networks of parvalbumin-positive interneurons in the basolateral amygdala. J Neurosci 2007;27:553563.

110 Samson RD, Pare D: A spatially structured network of inhibitory and excitatory connections directs impulse traffic within the lateral amygdala. Neuroscience 2006;141: 1599-1609.

111 Muller JF, Mascagni F, McDonald AJ: Postsynaptic targets of somatostatin-containing interneurons in the rat basolateral amygdala. J Comp Neurol 2007;500:513529.

112 Sosulina L, Meis S, Seifert G, Steinhauser C, Pape HC: Classification of projection neurons and interneurons in the rat lateral amygdala based upon cluster analysis. Mol Cell Neurosci 2006;33:57-67.

-113 Bauer EP, LeDoux JE: Heterosynaptic longterm potentiation of inhibitory interneurons in the lateral amygdala. J Neurosci 2004;24:9507-9512. 
114 Shin RM, Tsvetkov E, Bolshakov VY: Spatiotemporal asymmetry of associative synaptic plasticity in fear conditioning pathways. Neuron 2006;52:883-896.

- 115 Szinyei C, Heinbockel T, Montagne J, Pape HC: Putative cortical and thalamic inputs elicit convergent excitation in a population of GABAergic interneurons of the lateral amygdala. J Neurosci 2000;20:89098915.

-116 Zhou Y, Won J, Karlsson MG, Zhou M, Rogerson T, Balaji J, Neve R, Poirazi P, Silva AJ: CREB regulates excitability and the allocation of memory to subsets of neurons in the amygdala. Nat Neurosci 2009;12:14381443.

$>117$ Chowdhury N, Quinn JJ, Fanselow MS: Dorsal hippocampus involvement in trace fear conditioning with long, but not short, trace intervals in mice. Behav Neurosci 2005; 119:1396-1402.

-118 Asan E: The catecholaminergic innervation of the rat amygdala. Adv Anat Embryol Cell Biol 1998;142:1-118.

-119 Pinard CR, Muller JF, Mascagni F, McDonald AJ: Dopaminergic innervation of interneurons in the rat basolateral amygdala. Neuroscience 2008;157:850-863.

120 Shumyatsky GP, Tsvetkov E, Malleret G, Vronskaya S, Hatton M, Hampton L, Battey JF, Dulac C, Kandel ER, Bolshakov VY: Identification of a signaling network in lateral nucleus of amygdala important for inhibiting memory specifically related to learned fear. Cell 2002;111:905-918.

$\checkmark 121$ Huber D, Veinante P, Stoop R: Vasopressin and oxytocin excite distinct neuronal populations in the central amygdala. Science 2005;308:245-248.

>122 Labuschagne I, Phan KL, Wood A, Angstadt M, Chua P, Heinrichs M, Stout JC, Nathan PJ: Oxytocin attenuates amygdala reactivity to fear in generalized social anxiety disorder. Neuropsychopharmacology 2010; 35:2403-2413.

123 Zink CF, Stein JL, Kempf L, Hakimi S, Meyer-Lindenberg A: Vasopressin modulates medial prefrontal cortex-amygdala circuitry during emotion processing in humans. J Neurosci 2010;30:7017-7022.

-124 Ehninger D, Han S, Shilyansky C, Zhou Y, Li W, Kwiatkowski DJ, Ramesh V, Silva AJ: Reversal of learning deficits in a Tsc2+/mouse model of tuberous sclerosis. Nat $>_{136}$ Med 2008;14:843-848.

$>125$ Adusei DC, Pacey LK, Chen D, Hampson DR: Early developmental alterations in GABAergic protein expression in fragile $\mathrm{X}$ knockout mice. Neuropharmacology 2010; 59:167-171.
126 Brown V, Jin P, Ceman S, Darnell JC, O’Donnell WT, Tenenbaum SA, Jin X, Feng Y, Wilkinson KD, Keene JD, Darnell RB, Warren ST: Microarray identification of FMRP-associated brain mRNAs and altered mRNA translational profiles in fragile X syndrome. Cell 2001;107:477-487.

127 Curia G, Papouin T, Seguela P, Avoli M: Downregulation of tonic GABAergic inhibition in a mouse model of fragile $\mathrm{X}$ syndrome. Cereb Cortex 2009;19:1515-1520.

128 D'Hulst C, De Geest N, Reeve SP, Van Dam D, De Deyn PP, Hassan BA, Kooy RF: Decreased expression of the GABAa receptor in fragile X syndrome. Brain Res 2006;1121: 238-245.

129 El Idrissi A, Ding XH, Scalia J, Trenkner E, Brown WT, Dobkin C: Decreased GABA(A) receptor expression in the seizure-prone fragile X mouse. Neurosci Lett 2005;377: 141-146.

130 Gibson JR, Bartley AF, Hays SA, Huber KM: Imbalance of neocortical excitation and inhibition and altered up states reflect network hyperexcitability in the mouse model of fragile X syndrome. J Neurophysiol 2008;100:2615-2626.

131 Selby L, Zhang C, Sun QQ: Major defects in neocortical GABAergic inhibitory circuits in mice lacking the fragile $\mathrm{X}$ mental retardation protein. Neurosci Lett 2007;412: 227-232.

132 Centonze D, Rossi S, Mercaldo V, Napoli I, Ciotti MT, De Chiara V, Musella A, Prosperetti C, Calabresi P, Bernardi G, Bagni C: Abnormal striatal GABA transmission in the mouse model for the fragile $\mathrm{X}$ syndrome. Biol Psychiatry 2008;63:963-973.

133 Chang S, Bray SM, Li Z, Zarnescu DC, He C, Jin P, Warren ST: Identification of small molecules rescuing fragile $\mathrm{X}$ syndrome phenotypes in Drosophila. Nat Chem Biol 2008;4:256-263.

134 El Idrissi A, Boukarrou L, Dokin C, Brown WT: Taurine improves congestive functions in a mouse model of fragile $\mathrm{X}$ syndrome. Adv Exp Med Biol 2009;643:191198.

135 Brown N, Kerby J, Bonnert TP, Whiting PJ, Wafford KA: Pharmacological characterization of a novel cell line expressing human alpha(4)beta(3)delta GABA(A) receptors. Br J Pharmacol 2002;136:965-974.

36 Glykys J, Mody I: The main source of ambient GABA responsible for tonic inhibition in the mouse hippocampus. J Physiol 2007; 582:1163-1178.

137 Maguire JL, Stell BM, Rafizadeh M, Mody I: Ovarian cycle-linked changes in GABA(A) receptors mediating tonic inhibition alter seizure susceptibility and anxiety. Nat Neurosci 2005;8:797-804

$\checkmark 138$ Thompson BL, Levitt P: The clinical-basic interface in defining pathogenesis in disorders of neurodevelopmental origin. Neuron 2010;67:702-712.
39 Chakrabarti L, Best TK, Cramer NP, Carney RS, Isaac JT, Galdzicki Z, Haydar TF: Olig1 and olig2 triplication causes developmental brain defects in down syndrome. Nat Neurosci 2010;13:927-934.

140 Polleux F, Lauder JM: Toward a developmental neurobiology of autism. Ment Retard Dev Disabil Res Rev 2004;10:303317.

141 Carney RS, Alfonso TB, Cohen D, Dai H, Nery S, Stoica B, Slotkin J, Bregman BS, Fishell G, Corbin JG: Cell migration along the lateral cortical stream to the developing basal telencephalic limbic system. J Neurosci 2006;26:11562-11574.

142 Cocas LA, Miyoshi G, Carney RS, Sousa VH, Hirata T, Jones KR, Fishell G, Huntsman MM, Corbin JG: Emx1-lineage progenitors differentially contribute to neural diversity in the striatum and amygdala. J Neurosci 2009;29:15933-15946.

143 Waclaw RR, Ehrman LA, Pierani A, Campbell K: Developmental origin of the neuronal subtypes that comprise the amygdalar fear circuit in the mouse. J Neurosci 2010; 30:6944-6953.

144 Cocas LA, Georgala PA, Mangin JM, Clegg JM, Kessaris N, Haydar TF, Gallo V, Price DJ, Corbin JG: Pax6 is required at the telencephalic pallial-subpallial boundary for the generation of neuronal diversity in the postnatal limbic system. J Neurosci 2011;31: 5313-5324.

145 Ciocchi S, Herry C, Grenier F, Wolff SB, Letzkus JJ, Vlachos I, Ehrlich I, Sprengel R, Deisseroth K, Stadler MB, Muller C, Luthi A: Encoding of conditioned fear in central amygdala inhibitory circuits. Nature 2010; 468:277-282.

146 Hirata T, Li P, Lanuza GM, Cocas LA, Huntsman MM, Corbin JG: Identification of distinct telencephalic progenitor pools for neuronal diversity in the amygdala. Nat Neurosci 2009;12:141-149.

147 Quartz SR, Sejnowski TJ: Liars, Lovers, and Heroes. New York, HarperCollins Publishers Inc, 2002.

148 Hammock EA, Levitt P: The discipline of neurobehavioral development: the emerging interface of processes that build circuits and skills. Hum Dev 2006;49:294-309.

149 Deutsch SI, Rosse RB, Mastropaolo J: Environmental stress-induced functional modification of the central benzodiazepine binding site. Clin Neuropharmacol 1994; 17:205-228.

150 Domschke K, Zwanzger P: GABAergic and endocannabinoid dysfunction in anxiety future therapeutic targets? Curr Pharm Des 2008;14:3508-3517. 